\title{
Creating a legal framework for urban agriculture: Lessons from Flint, Michigan
}

\author{
Megan Masson-Minock, AICP \\ Deirdra Stockmann ${ }^{\mathrm{b}}$
}

Submitted 1 July 2010 / Accepted 16 September 2010/ Published online 30 November 2010

Citation: Masson-Minock, M., \& Stockmann, D. (2010, Fall). Creating a legal framework for urban agriculture: Lessons from Flint, Michigan. Journal of Agriculture, Food Systems, and Community Development, 1(2): 91-104. doi:10.5304/jafscd.2010.012.007

Copyright (C) 2010 by New Leaf Associates, Inc.

\begin{abstract}
Urban agriculture is not new to Flint, Michigan. Like most cities around the world, Flint has been home to back yard and small community gardens throughout its history. Today, over 150 churches, shelters, and neighborhood block clubs grow vegetables in the city. As the most recent wave of interest in urban agriculture swelled in Flint, however, many enterprising gardeners encountered city ordinances that barred certain activities and failed to define land uses common for small-scale food production. As a result, advocates pressed the Flint Planning Commission to change codes in order to enable a wider range of agricultural activities within the city limits. This case study highlights how the legal framework in Flint discouraged efforts to expand the scope of community gardening and how local nongovernmental organizations inter-

a Planner, ENP \& Associates, P.O. Box 131095, Ann Arbor, Michigan, 48113 USA, megan@enp-associates.com

${ }^{\mathrm{b}}$ corresponding author: PhD Candidate, Taubman College of Architecture and Urban Planning, University of Michigan, 2000 Bonisteel Boulevard, Ann Arbor, MI 48109 USA, deirdra@umich.edu
\end{abstract}

vened, opening a vibrant public dialogue about urban agriculture. We discuss the importance of public input and education in efforts to amend city policies to support a range of urban agricultural activities, outline the strategies used in Flint, and identify some of the challenges that arose in this process.

\section{Keywords}

urban agriculture, community food system

planning, urban planning, zoning

\section{Introduction}

Urban agriculture is not new to Flint, Michigan. Like most cities around the world, Flint has been home to back yard and small community gardens throughout its history. In recent years, as vacant lots became available, people have expanded their yards and gardens. Today, countless individual residents and over 150 churches, shelters, and neighborhood block clubs grow vegetables in the city.

As the most recent wave of interest in urban agriculture has swelled in Flint, however, many 
gardeners and potential agrepreneurs ${ }^{1}$ encountered city ordinances that barred certain activities and failed to define land uses common in small-scale food production. As a result, advocates pressed the Flint Planning Commission to consider several changes to the codes that would explicitly enable a wider range of agricultural activities within the city limits. This led to a vibrant public dialogue that highlighted competing ideas of what a city is and what types of land uses and activities are appropriate within it. After a year, only some of the issues were resolved; nevertheless, there was nearly unanimous agreement that food system issues would figure into future planning.

In this case study we examine Flint's foray into urban agriculture planning. We begin with a brief discussion of the literature and previous research that provides a context for emerging food system planning in Flint and other U.S. cities. Then we describe how urban agriculture came to be a policy issue in Flint, identify the legal impediments to expanded urban agriculture efforts in the city, and chronicle the attempt to remove some of these impediments. In our discussion, we consider the critical, if initially unanticipated, role that the public played in the process and offer recommendations for other cities, planners, and advocates based on the Flint experience.

\section{Food Systems and Urban Planning}

While food concerns were a fringe issue 10 years ago, urban planning scholars and practitioners increasingly appreciate the role that local and regional-level planning can play in food policymaking and systems change (American Planning Association, 2007). In recent years, scholars have identified myriad ways in which the food system affects and is affected by the social and infrastructure systems that define the more traditional scope of urban planning, including transportation, urban design, economic development, and environmental conservation (Campbell, 2004;

\footnotetext{
${ }^{1}$ Hewitt (2009) uses this term to refer to a new wave of entrepreneurs finding a niche in the growing market for local, small-scale, and sustainable food production.
}

Pothukuchi \& Kaufman, 1999; Pothukuchi \& Kaufman, 2000; Wekerle, 2004).

As a large sector of the economy, the food system -including farms, processing facilities, distribution centers, and retailers-comprises a major land use and provides many jobs in cities, suburbs, and rural areas alike (Pothukuchi \& Kaufman, 1999). All stages of the food system consume energy and other resources, and many result in pollutants released into the air, soil, and water (Heller \& Keoleian, 2003). Because nearly all of the food consumed in the U.S. is moved at least some distance from farm to point of sale, transportation networks and policy interact with the food system on a daily basis and affect access to food (Pothukuchi \& Wallace, 2009). Perhaps most important, nourishing food is necessary for good health, and insufficient access to nutritious, culturally appropriate food has been linked to both hunger and obesity (Morland, Wing, \& Roux, 2002; Morland, Wing, Roux, \& Poole, 2002). The American Planning Association's Policy Guide on Community and Regional Food Planning 2 (2007) concisely summarizes recent research on these relationships and generates recommendations for planning practice and policy.

While cities throughout the country experience the impact of the food system on public health and social well-being, the challenges are often severe in communities with high levels of unemployment and poverty, poor public transportation systems, and the out-migration and vacant land associated with de-industrialization. A growing body of scholarly work and practice focuses on how community gardening and other forms of urban agriculture might help address these issues by providing fresh food, employment, and community green space (e.g., Bingen, Colasanti, Fitzpatrick, \& Nault, 2009; Brown \& Jameton, 2000; Kaufman \& Bailkey, 2000). ${ }^{3}$ Much has been published about

\footnotetext{
${ }^{2}$ http://www.planning.org/policy/guides/adopted/food.htm

${ }^{3}$ Numerous master's projects and exploratory committees have investigated the characteristics and potential of urban agriculture in cities throughout the U.S. See, for instance,
} 
urban agriculture in the Global South, but the literature lags behind the growing movement in North America. We have few examples in the scientific literature that describe the practical challenges and social dynamics of planning for urban agriculture in the U.S. generally and in its old industrial core cities in particular. There is a great deal to learn about how these processes unfold in practice and how different types of policies work in different communities.

\section{Data and Methods}

This case study of emerging urban agriculture planning in Flint, Michigan, combines participant observation and reflection with observation (by a nonparticipant) and qualitative research. Analysis of Flint's city codes and of other cities' relevant plans and policies was conducted by one of the authors as part of the planning process. The authors, who are independent researchers, later conducted semistructured, in-depth interviews with participants and observers. Interviewees included members of the Flint Planning Commission, the Flint zoning administrator, representatives of nongovernmental organizations, urban gardeners, and other Flint residents. Detailed interview notes were open-coded for emergent themes. Direct observation and review of meeting minutes, reports, newspaper articles, and nongovernmental organizations' publications supplemented and validated the interview data and practitioner reflection.

\section{Backeground on Flint}

Flint, Michigan, is a modest Great Lakes city that lays bare the social and economic repercussions of the rise and fall of U.S. manufacturing in the twentieth century. Located on the Flint River in central Michigan, the city anchors the "thumb" region of the state- a large, rural peninsula where sugar beet, dry bean, and wheat fields run to the shores of Lake Huron. As the birthplace and home of General Motors, Flint became the "Vehicle City" in the early twentieth century. Flint grew steadily to a population of almost 200,000 in 1960

Balmer et al. (2005), Bickerdike et al. (2010) and Felsing (2002).
(U.S. Census Bureau, 1990), but the city soon began losing manufacturing jobs to the suburbs, and later to overseas countries (Highsmith, 2009).

Today, the Flint population hovers just over 100,000 , less than half the number of people the city was planned for in the 1960s. The depopulation has resulted in about 11,000 vacant properties within the city. The median household income in 2008 was $\$ 28,584$, just over half the U.S. median according to the American Community Survey (U.S. Census Bureau, 2009). In the face of a shrinking tax base, local government has cut back city services. Consistency in leadership has been a challenge as well; five city administrations cycled through City Hall between 2002 and 2009.

\section{Many Hoops To Go Through}

In 2007, a small youth development organization in Flint, Urban Community Youth Outreach (UCYO), received a grant to erect a hoop house so that the young people in the program could raise seedlings for their established community garden. Using the hoop house, which consists of curved metal "hoops" covered in plastic, the organization could grow vegetables most of the winter without an additional heat source. Because the Michigan growing season is limited, this technology has increased in popularity among large-scale commercial growers and small gardening organizations alike that seek to extend or intensify production (Conner, Montri, Montri, \& Hamm, 2009).

The Genesee County Land Bank helped UCYO secure six formerly vacant lots in Flint across the street from the UCYO garden. With the land prepared, the materials purchased and the groundbreaking set, the director of the program went to acquire a building permit from the city. To her surprise, she was told that her plans required a full site plan review, a level of scrutiny for which she was not prepared. Hoop houses were not defined in the city zoning ordinance or the state building code, and officials considered the structure to be permanent because it was intended to stand longer than 180 days. Based on existing policy, plans in which a hoop house is the only permanent structure on a parcel must go through site plan 
review, a formal administrative process to verify that building plans comply with the zoning ordinance. The designation as a "permanent structure" necessitated professional architectural drawings and calculations for wind and snow loads.

Site plan review and the building permit process took more than two years, much longer than expected and than is usual for approval of a building in Flint or surrounding communities. After administrative review, the city of Flint requires the planning commission to review and approve all site plans during one of their bimonthly meetings. Because hoop houses were not defined in the state building code and the city had not reviewed an application for a similar structure such as a greenhouse in decades, the building safety department had limited information about the safety of the hoop house structure and thus required additional time and review. During this time, the Ruth Mott Foundation funded the construction of a hoop house for a youth group in Mount Morris Township, just to the north of the Flint River; in contrast, the approval process took only a few months.

\section{Policy Impediments to Urban Agriculture in Flint} The Flint zoning ordinance has not been updated for over 20 years. It contains inflexible site plan review requirements and procedures and lacks mechanisms for waivers and exceptions common in more recently developed zoning codes. ${ }^{4}$ With only a few specific exceptions, all permanent structures proposed as the primary or principal use on a parcel require site plan approval by the Flint Planning Commission. Drawings must include a long list of items such as building elevations, which can be waived only by the planning commission.

The zoning ordinance allows "customary agricultural uses including noncommercial nurseries and greenhouses, but expressly excluding the keeping

\footnotetext{
${ }^{4}$ Innovations and flexibility in other codes include a sketch plan option where sealed drawings are not needed, basic administrative review, waiver of requirements by staff, and a planned unit development option for projects that offer public benefit but do meet the letter of the ordinance.
}

of farm animals" in its residential and commercial zones. Neither "noncommercial nursery" nor "customary agricultural uses," however, are defined in the ordinance. As a result, the planning commission had to deliberate whether the UCYO hoop house was a noncommercial nursery. The ordinance also did not specify standards for parking, screening, and lighting for agricultural uses, which the planning commission had to debate and define.

Even after the hoop house was erected, the city ordinances caused obstacles. Since the hoop house was not a residence, the city would not pick up the trash, and because no one resided at the address, the municipal water system could not be used. Until the organization raised the funds to drill a well, youth group members brought water to the site and carried garbage away.

\section{Changing the Legal Framework in Flint}

Urban Community Youth Outreach was not the only group interested in expanding its gardening efforts. In 2007 and 2008, the Genesee County Land Bank and the Ruth Mott Foundation saw a marked increase in requests for land and funding for urban agriculture projects in Flint. Both organizations saw a need for a more transparent, navigable approval process and fewer barriers to urban agricultural uses in the city. In fall 2008, the Ruth Mott Foundation paid ENP \& Associates (including author Masson-Minock) to provide professional planning services to the City of Flint Planning Commission to update city ordinances to allow for, if not encourage, urban agriculture. The Genesee County Land Bank served as the supervisor of ENP, as the funding was part of a larger Ruth Mott Foundation grant given to the Land Bank for stabilization of vacant land. An update to Flint's master plan was not considered, due to the political climate and limited budget.

ENP began with a diagnostic review of the city ordinances to identify challenges to urban agriculture. Unaware of an existing template for such a review, ENP developed a process modeled in part

${ }^{5}$ Flint Zoning Ordinance, Article II. Chapter 50, A-1, § 50-17, page 26. 
on checklists designed to assess code compliance with water quality standards. The process included interviews with key informants and a close reading of the codes, noting any ordinance that may affect urban agriculture-related activities. Table 1 summarizes the findings from the review. ENP also researched zoning and policies encouraging urban agriculture in Seattle, Toronto, and Philadelphia, and held an educational workshop with the Flint Planning Commission on different types of urban agriculture in spring 2009. Based on this experience, we developed a diagnostic review framework, which is included in the appendix to this study.

\section{Public Input}

By summer 2009, the debate had been distilled to three key areas: hoop houses, keeping animals, and growing food for sale. Two public workshops sponsored by the Ruth Mott Foundation and the Land Bank were held in summer 2009 to gather input about these three concerns. The planning commission specifically requested that these sessions include a cross-section of the community, rather than just "the choir," referring to urban agriculture proponents. Participants were recruited through email announcements, flyers placed at churches, community centers, and retail hubs, and

\section{Table 1. Ordinance Challenges to Urban Agriculture in Flint, Michigan}

\begin{tabular}{|c|c|}
\hline Ordinance & Challenge to Urban Agriculture \\
\hline $\begin{array}{l}\text { Zoning Ordinance } \\
\text { Definitions }\end{array}$ & $\begin{array}{l}\text { What types of agricultural uses are allowed is unclear since no definitions dealing with } \\
\text { agriculture are provided. }\end{array}$ \\
\hline $\begin{array}{l}\text { Zoning Ordinance } \\
\text { Appearance Standards }\end{array}$ & $\begin{array}{l}\text { While the regulation is currently used in historic areas, it could be used to prevent the } \\
\text { building of a hoop house or greenhouse in an established neighborhood. }\end{array}$ \\
\hline $\begin{array}{l}\text { Zoning Ordinance Site } \\
\text { Plan Review }\end{array}$ & $\begin{array}{l}\text { Any structure, defined by the zoning ordinance as any structure anchored to the ground, } \\
\text { must go through site plan review by the planning commission with the exception of fewer } \\
\text { than three single-family dwellings. }\end{array}$ \\
\hline $\begin{array}{l}\text { Zoning Ordinance Use } \\
\text { Districts }\end{array}$ & $\begin{array}{l}\text { "[C] ustomary agricultural uses including noncommercial nurseries and greenhouses, but } \\
\text { expressly excluding the keeping of farm animals" are listed as principal permitted uses in A- } \\
1, A-2, B, B-1, C-1, C-2 \text { and D-1 zones (if the D-1 property abuts a residential zone). } \\
\text { No agricultural uses are currently allowed within the commercial and industrial districts of } \\
\text { the city. The sale and processing of food within the city is restricted exclusively to these } \\
\text { districts, however. }\end{array}$ \\
\hline $\begin{array}{l}\text { Zoning Ordinance Off- } \\
\text { street parking \& loading }\end{array}$ & $\begin{array}{l}\text { The parking and loading requirements do not have specific requirements for agricultural } \\
\text { uses. }\end{array}$ \\
\hline Air Pollution Ordinance & $\begin{array}{l}\text { Section 4-13 bars open burning of refuse. Gardening or farm sites are sometimes best } \\
\text { cleared by a controlled burn rather than the use of chemicals. }\end{array}$ \\
\hline $\begin{array}{l}\text { Animals and Fowl } \\
\text { Ordinance }\end{array}$ & $\begin{array}{l}\text { The ordinance restricts all meat and egg production to the mainstream industrial food chain, } \\
\text { allowing animals to be kept only at slaughterhouses. It does not allow for poultry or domestic } \\
\text { fowl on residentially zoned lots. }\end{array}$ \\
\hline $\begin{array}{l}\text { Business and } \\
\text { Occupations General } \\
\text { Ordinance }\end{array}$ & This ordinance has a number of restrictions on who may sell food and how food is sold. \\
\hline Fences Ordinance & $\begin{array}{l}\text { The regulations for fence placement and materials in the residential zoning districts, where } \\
\text { agricultural uses are allowed, are difficult to understand and may not be appropriate for } \\
\text { gardeners. }\end{array}$ \\
\hline Nuisance Ordinance & $\begin{array}{l}\text { Some provisions of this ordinance could be used to limit composting, an essential activity in } \\
\text { organic gardening. }\end{array}$ \\
\hline Parks Ordinance & $\begin{array}{l}\text { This ordinance places restrictions on gardening in the city's parks. It bans picking or } \\
\text { breaking flowers and plants, and the removal of turf. }\end{array}$ \\
\hline $\begin{array}{l}\text { Refuse, Garbage and } \\
\text { Weeds Ordinance }\end{array}$ & $\begin{array}{l}\text { This ordinance does not specify what department would be responsible for refuse collection } \\
\text { at an urban agricultural enterprise of any size and does not specify the type of trash } \\
\text { receptacle required. }\end{array}$ \\
\hline
\end{tabular}


local media, including television, radio, and the Flint Journal mentioning the events. The workshops had a high turnout for community meetings, with about 162 people attending. While most of the planning commissioners considered the meetings to be sufficiently representative, a few did not believe that the workshop results reflected their ward's interests. Although demographic data about the 162 participants was not made available, interviewees reported that a mix of Flint residents and residents of neighboring townships attended. Some commissioners noted that few if any residents of their ward participated, and that the demographic make-up of the meetings did not mirror that of the city overall.

At each workshop, the UCYO director and other local growers presented their experiences growing food in Flint. Participants received information packets that included detailed descriptions of each of the three issues and how they are regulated in other communities. Small groups, randomly assigned, discussed how hoop houses, keeping animals, and growing food for sale might positively or negatively affect their neighborhood, and shared their concerns and thoughts. Each small group had a facilitator to encourage discussion and a notetaker to document feedback. ENP compiled the information into a comprehensive report that served as a resource for the planning commission when discussing whether and how to change city ordinances.

\section{Hoop Houses}

By an overwhelming margin the workshop participants felt that hoop houses should be allowed in Flint, including in residential areas, and most felt the approval process should be simplified. Participants did express concern, however, that the hoop houses should be maintained and secured from vandalism and squatting. A few groups proposed that the surrounding neighbors should be notified and their input sought when a hoop house was proposed.

When discussing regulations, the planning commission considered adding a definition of a hoop house to the zoning ordinance, specifying the structure as a conditional use, or special land use, in residential and commercial areas. While these amendments would clarify the identity of hoop houses, designation as a conditional use would add processing time, costs, and risks for any group proposing a hoop house, as a proposed conditional use requires a higher level of scrutiny.

Instead of changing the zoning ordinance, the planning commission agreed to change its administrative rules to allow a streamlined approval process for hoop houses, as long as the plans were based on three hoop house prototypes under development by the Michigan State University Department of Horticulture and the Michigan State University Student Organic Farm. ${ }^{6}$ Preapproved hoop house designs will eliminate the cost of producing sealed and stamped drawings for each proposal. At the time of this writing, the prototypes were under review.

\section{Keeping of Animals}

Participants in the public workshop sessions were asked to consider whether bees, goats, and chickens should be allowed in Flint. Participants were divided on this issue. Many of the 24 small groups supported keeping of animals, especially chickens and bees. Four of the groups decided that animals should not be allowed. Participants voiced concerns about noise and odors associated with chickens and goats, safety (particularly of children with respect to bee stings and pecking hens), and the potential for cruelty to animals. Consistent with support for other types of urban agriculture, those in support of keeping small animals in the city cited health benefits and personal and community empowerment.

The planning commission studied ordinances allowing for animals in other cities, specifically Ann Arbor (Michigan), Cleveland and Seattle. All ordinances limit the number of animals, establish where animals can be kept, and how far structures

\footnotetext{
${ }^{6}$ Michigan State Department of Horticulture website: http://www.hrt.msu.edu; Michigan State Student Organic Farm website: http://www.msuorganicfarm.com
} 
and pens must be from property lines and adjacent houses. Some cities require licenses to be renewed on an annual or biannual basis. Ann Arbor requires a petition from all neighboring property owners giving their permission for the applicant to keep chickens.

The planning commission decided to allow only chickens. They were concerned about bee stings, and ruled that goats were not appropriate in Flint due to potential odor problems and the fencing needed. The commission recommended to the city council an ordinance that would allow up to four chickens in a coop in residential back yards if all adjacent property owners gave permission. The proposed ordinance requires the applicant to have completed a training course on keeping chickens, which a new collaborative called Edible Flint may develop and implement. The Flint City Council debated the chicken ordinance in spring 2010 and sent it to a council committee for further study.

\section{Growing Food for Sale}

The workshop participants generally supported growing food for sale, viewing urban farming as a source of jobs, food, and education. Their concerns focused on items regulated by state and federal laws that override local legislation; food safety and soil quality, which are monitored by the USDA; the use of pesticides; and the locations where the food produced can be sold. Both of the latter items are regulated by the Michigan Right to Farm Act.

From discussions among the commissioners and the public there emerged a distinction between gardening and urban agriculture. Gardening referred to the widely accepted practice of growing vegetables in back yards and vacant lots, by residents, block groups, and youth groups. Urban agriculture or city farming was perceived as a forprofit venture that could jeopardize the redevelopment of neighborhoods, if not carefully located and regulated.

The planning commission decided not to add definitions or change allowed uses dealing with agriculture, largely due to the Michigan Right to
Farm Act. This state law dictates that a farm operation shall not be found to be a nuisance if it conforms to Generally Accepted Agricultural Management Practices (GAAMPs) determined by the Michigan Department of Agriculture. Recent court cases have treated urban gardens and greenhouses the same as rural farm operations under the Right to Farm Act. ${ }^{7}$ The Flint Planning Commission did not want to risk allowing land uses associated with nuisances regulated by the state. Since gardening efforts had developed within the current legal framework, the planning commission recommended minor adjustments to the existing regulations for yard waste and trash pick-up in order to smooth the way for gardening, but not to undertake a more comprehensive revision as advocates had originally hoped for in the beginning of this year-long process.

\section{Lessons from Flint}

Given the growing interest in small-scale food production in Flint, two nongovernmental organizations-Genesee County Land Bank and the Ruth Mott Foundation-working with the ENP \& Associates planning firm proposed several changes to the zoning ordinance. Two public input sessions engaged over 160 people and provided critical feedback for the policymakers. The planning commission spent countless hours learning about urban gardening and farming, hearing testimony from community members, and debating the proposed changes.

While sympathetic to the needs and interests of residents who garden, and willing to make minor changes to address their needs, the planning commission felt that more extensive public input and mapping was needed to ascertain where and how urban agriculture should be allowed in Flint. The Flint Planning Commission, like most planning commissions, normally addresses sitespecific planning and zoning issues. Other than master planning, it is not usually engaged in

\footnotetext{
${ }^{7}$ Woodland Hills Homeowners Assn of Thetford Twp v. Thetford Twp and Roger Allison (2008), retrieved from http://www.michbar.org/opinions/appeals/2008/052008/39 418.pdf
} 
citywide policy-making. With no language in the city's master plan validating the proposed changes to the city ordinances to support urban agriculture, the commission chose to accept only some of the proposed changes and to leave several restrictions in place.

\section{Recommendations}

Though de-industrialization is extreme in Flint, the city is not alone in the experience of depopulation and financial distress associated with the loss of major economic sectors. Today nearly all cities are struggling with the effects of the recession and the recent housing foreclosure crisis. As municipalities strive to adapt to this turbulent social and economic environment, and as the urban agriculture movement continues to grow, more cities may feel public pressure to rethink the role of food production in urban areas.

While the specific policies, actors, and debates reflected the legal and political climate in Flint, the city's foray into planning and policy-making for urban agriculture is an experience from which others might learn. While we do not profess that a single case is sufficient for a full understanding of the issues and conflicts that characterize local urban agriculture policy-making, we offer the following interrelated propositions based on the Flint experience.

- Assess whether policy changes are necessary. Planners and advocates may adapt and apply the Urban Agriculture Ordinance Assessment provided in the appendix to analyze the extent to which local policies support or discourage urban agriculture and other food-system activities. In some communities, urban agriculture uses may be allowed under existing policy; therefore, efforts to educate planning, zoning, and building administrators may be the most pressing need.

- Provide for public education and input. Most people are cautious about allowing unfamiliar activities in their neighborhoods and communities. Until residents feel fully informed about what "urban agriculture" means for their block or ward or city, they are unlikely to support it.

- If policy changes are deemed necessary, an inclusive and community-based approach is essential for giving validity and legitimacy to proposed revisions or plans. Policymakers want to hear from a broad cross-section of the public. Proposed policies should reflect, as well as possible, the wishes and concerns of the community. Proposed new or amended policies will require numerous edits and amendments to address resident concerns, such as how to regulate chicken keeping.

- Policy change takes time. While some cities may pass enabling policy for urban agriculture relatively quickly, the process may take many months or years in cities like Flint in which there are varying degrees of awareness about urban food production and many different opinions about what types of activities are appropriate in the urban context. Advocates, funding agencies, and planning departments should prepare for thorough assessment, ongoing public education, and extensive, authentic community input.

Further research is needed to test and refine these propositions. From our work, we have learned that in developing new policies, local officials prefer to learn from cases with which they identify and in which they can see elements of their own community. As more municipalities engage in planning and policy change around food production and other community food system components, we will need in-depth case studies from a wide range of cities as well as larger and comparative studies engaging multiple research methods. We invite practitioners, advocates, and scholars to apply the diagnostic tool we created based on our experience and research in Flint. This resource needs to be 
honed and validated through testing in a range of municipal environments.

Reflecting on the process, some project partners felt that a more comprehensive planning process might have yielded different results, had time and resources allowed. Nevertheless, the conversation about urban agriculture planning and policy in Flint continues. At public meetings, many residents are still debating issues such as raising poultry and growing food for sale. A new farm is underway in partnership with the city parks department. Planning commissioners, among others, expect urban agriculture to be addressed in the next master plan, reflecting public interest and demand. To many advocates of urban agriculture and public participation in planning, this continued dialogue is a success unto itself and a critical step toward reshaping our cities to support food system change.

\section{Disclaimer}

It should be noted that as an employee of ENP \& Associates, coauthor Megan Masson-Minock worked with the City of Flint Planning Commission on the issues described in this paper. Her work was completed before writing this paper. She was not compensated in any way for writing this piece and has no financial interest at stake.

\section{References}

American Planning Association. (2007). Policy guide on community and regional food planning. Retrieved from http://www.bracrtf.com/documents/APAPolicyG uide-CommunityandRegionalFoodPlanning.pdf

Balmer, K., Gill, J., Kaplinger, H., Miller, J., Peterson, M., Rhoads, A., ...Wall, T. (2005). The diggable city: Making urban agriculture a planning priority. Nohad A. Toulan School of Urban Studies and Planning. Retrieved from http://www.portlandonline.com/ shared/cfm/image.cfm?id=122587

Bickerdike, C., DiLisio, C., Haskin, J., McCullagh, M., \& Pierce-Quinonez, M. (2010). From factories to fresh food: Planning for urban agriculture in Somerville. Field projects, Tufts Department of Urban and Environmental Policy and Planning. Retrieved from http://www.ase.tufts.edu/uep/Degrees/field project reports/2010/Team 5 Final Report.pdf
Bingen, J., Colasanti, K., Fitzpatrick, M., \& Nault, K. (2009). Urban agriculture. In L. Phoenix (Ed.), Critical food issues: Problems and state-of-the-art solutions worldwide (pp. 109-122). Santa Barbara, CA: ABCCLIO, LLC.

Brown, K. \& Jameton, A. (2000). Public health implications of urban agriculture. Journal of Public Health Policy, 21(1), 20-39. doi:10.2307/3343472

Campbell, M. C. (2004). Building a common table: The role for planning in community food systems. Journal of Planning Education and Research, 23(4), 34155. doi:10.1177/0739456X04264916

City of Flint Zoning Ordinance. Article II. Chapter 50: Zoning, A-1: Single-Family Low Density District, \& 50-17: Principle Permitted Uses, p. 26. Flint, MI.

Retrieved from http://www.ci.flint.mi.us/Planning/ ZONING ORD.pdf

Conner, D., Montri, A. D., Montri, D. N., \& Hamm, M. W. (2009). Consumer demand for local produce at extended season farmers' markets: Guiding farmer marketing strategies. Renewable Agriculture and Food Systems, 24(4), 251-259. doi: $10.1017 / \mathrm{S} 1742170509990044$

Felsing, R. D. (2002). The pros and cons of zoning for community gardens. Unpublished manuscript, The Madison Ad-Hoc Committee on Community Gardens, Department of Urban and Regional Planning, University of Wisconsin-Madison.

Heller, M. \& Keoleian, G. (2003). Assessing the sustainability of the US food system: A life cycle perspective. Agricultural Systems, 76(3), 1001-1041. doi:10.1016/S0308-521X(02)00027-6

Hewitt, B. (2009). The town that food saved: How one community found vitality in local food. New York, NY: Rodale.

Highsmith, A. (2009). Demolition means progress: Urban renewal, local politics, and state-sanctioned ghetto formation in Flint, Michigan. Journal of Urban History, 35(3), 348-368. doi:10.1177/0096144208330403

Hodgson, K. (2009). Where food planning and health intersect. Planning, 75(8), August/September, 9-13.

Kaufman, J. \& Bailkey, M. (2000). Farming inside cities: Entrepreneurial urban agriculture in the United States. Working paper, Lincoln Institute of Land Policy, Cambridge, MA. Retrieved from http://www.urbantilth.org/wp-content/uploads/ 2008/10/farminginsidecities.pdf 
Morland, K., Wing, S. B., \& Roux, A. D. (2002). The contextual effect of the local food environment on residents' diets: The Atherosclerosis Risk in Communities study. American Journal of Public Health, 92(11), 1761-1767. doi:10.2105/AJPH.92.11.1761

Morland, K., Wing S. B., Roux A. D., \& Poole, C. (2002). Neighborhood characteristics associated with the location of food stores and food service places. American Journal of Preventive Medicine, 22(1), 23-29.

Pothukuchi, K., \& Kaufman, J. (1999). Placing the food system on the urban agenda: The role of municipal institutions in food systems planning. Agriculture and Human Values, 16, 213-24. doi:10.1023/A:1007558805953

Pothukuchi, K., \& Kaufman, J. (2000). The food system: A stranger to the planning field. Journal of the American Planning Association, 66(2), 113-24. doi:10.1080/01944360008976093

Pothukuchi, K. \& Wallace, R. (2009). Sustainable food systems: Perspectives on transportation policy. In Malkefzali, S. (Ed.), Healthy, Equitable Transportation Policy: Recommendations and Research (pp. 113-130). Oakland, CA: PolicyLink.
Shaw, L. (2009, July 7). Flint to consider ordinance changes to enhance urban agriculture. The Flint Journal. Retrieved from http://blog.mlive.com/ get-healthy-in-genesee $/ 2009 / 07 /$ flint to consider ordinance ch.html

U.S. Census Bureau. (1990). 1990 Census of Population and Housing: Population and housing unit counts. CPH-2-1. Retrieved from www.census.gov/prod/ cen1990/cph2/cph-2-1-1.pdf

U.S. Census Bureau. (2009). Median household income for states: 2007 and 2008 American Community Surveys. Retrieved from http://www.census.gov/ prod/2009pubs/acsbr08-2.pdf

Wekerle, G. (2004). Food justice movements: Policy, planning, and networks. Journal of Planning Education and Research, 23(4), 378-386. doi: $10.1177 / 0739456$ X04264886

Woodland Hills Homeowners Association of Thetford Township. v. Thetford Township and Roger Allison, No. 275315 Mich. Ct. of Appeals (2008), aff'd, 05-081537-NZ (Genesee Cir. Ct.). Retrieved from http://www.michbar.org/opinions/ appeals/2008/052008/39418.pdf 


\section{Appendices}

\section{Appendix A. Urban Agriculture Ordinance Assessment}

\begin{tabular}{|c|c|c|}
\hline Questions & Yes/No & Follow-up Action/Question \\
\hline \multicolumn{3}{|l|}{ Application Procedures } \\
\hline 1. Does the zoning ordinance allow for staff to & Yes & \\
\hline approve applications? & No & See Action A. \\
\hline \multirow{2}{*}{ Is a sketch plan, a drawing of the site with less } & Yes & \\
\hline & No & See Action A. \\
\hline
\end{tabular}

Is a public hearing required? If

3. Are agricultural or gardening uses listed as allowed uses in the zoning ordinance? yes, see Action $B$.

\section{ander}

No

4. Are agricultural or gardening uses listed in the Definitions section?

\begin{tabular}{cl} 
Yes & $\begin{array}{l}\text { If the definitions do not match } \\
\text { with state laws, see Action C. }\end{array}$ \\
\hline No & See Action C.
\end{tabular}

\section{Residential Garden}

5. Does the zoning ordinance recognize lots adjacent to another owned by the same entity as a single lot or zoning lot?

Yes

If not allowed where desired, see Action D.

6. Is an accessory structure, such as a shed or small greenhouse or hoop house, allowed if it is the only structure on a lot?

\begin{tabular}{cc} 
Yes & \\
\hline No & See Action C. \\
\hline Yes & \\
\hline No & See Action C.
\end{tabular}

\section{Community Garden}

7. Is a community garden allowed as an accessory use (a second activity on the lot)?

\begin{tabular}{cl} 
Yes & $\begin{array}{l}\text { If not allowed where desired, see } \\
\text { Action D. }\end{array}$ \\
\hline No & See Action C. \\
\hline Yes & See Action B. \\
\hline No &
\end{tabular}

8. Does a shed, greenhouse or hoop house require approval by an appointed or elected body (planning commission or City Council)?

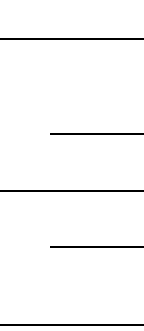

\section{Back Yard Animals}

9. Is keeping of animals (chickens, bees, goats) legal?

$\begin{array}{ll}\text { Yes } & \\ \text { No See Action D. }\end{array}$

\section{Market Garden}

10. Are market gardens allowed?

\begin{tabular}{cl} 
Yes & $\begin{array}{l}\text { If not allowed where desired, see } \\
\text { Action D. }\end{array}$ \\
\hline No & See Action D. \\
\hline Yes & See Action C. \\
\hline No &
\end{tabular}


12. Who approves permits for building construction?

\begin{tabular}{cl} 
Public hearing & See Action B. \\
\hline Public body & See Action B. \\
\hline Staff &
\end{tabular}

\section{Fences}

13. Are temporary fences allowed?

\begin{tabular}{cl} 
Yes & $\begin{array}{l}\text { If time period less than growing } \\
\text { season, see Action C. }\end{array}$ \\
\hline No & See Action C. \\
\hline Yes & \\
\hline No & See Action C.
\end{tabular}

\section{All Urban Agricultural and Gardening Uses}

\begin{tabular}{|c|c|c|}
\hline \multirow{2}{*}{ 15. Are parking requirements defined? } & \multicolumn{2}{|l|}{ Yes } \\
\hline & No & See Action C. \\
\hline \multirow{2}{*}{ 16. Are loading requirements defined? } & Yes & \\
\hline & No & See Action C. \\
\hline \multirow{2}{*}{ 17. Are signs allowed? } & Yes & \\
\hline & No & See Action C. \\
\hline \multirow{2}{*}{ 18. Is screening required? } & Yes & See Action C. \\
\hline & No & \\
\hline \multirow{2}{*}{ 19. Is composting allowed? } & Yes & \\
\hline & No & See Action C. \\
\hline \multirow{2}{*}{$\begin{array}{l}\text { 20. Are food crops excluded from weeds definition in } \\
\text { any weed or nuisance ordinance? }\end{array}$} & Yes & \\
\hline & No & See Action C. \\
\hline \multirow{2}{*}{$\begin{array}{l}\text { 21. Is municipal garbage pickup available to urban } \\
\text { agricultural and gardening uses? }\end{array}$} & Yes & \\
\hline & No & See Action C. \\
\hline \multirow{2}{*}{$\begin{array}{l}\text { 22. Is municipal water available to urban agricultural } \\
\text { uses? }\end{array}$} & Yes & \\
\hline & No & See Action C. \\
\hline \multirow{2}{*}{ 23. Is a prescribed burn allowed? } & Yes & \\
\hline & No & See Action C. \\
\hline \multirow{2}{*}{ 24. Is a food garden allowed in municipal parks? } & Yes & \\
\hline & No & See Action C. \\
\hline
\end{tabular}

Action A: $\quad$ Your community's zoning ordinance lacks flexible approval procedures, which may restrict affordable, timely approvals of urban agricultural land uses and associated buildings, as well as other developments in your community. Discuss with the Planning or Community Development Department as well as the elected officials in your community the need to update these procedures. If your community's zoning ordinance has not been updated in the past 10 years, a complete overhaul should be considered. 
Action B: $\quad$ Your community's zoning ordinance does not allow for quick and low-cost approvals for urban agricultural uses and buildings. Discuss with your community's Planning or Community Development Department why staff approval and sketch plans are not options and how and if these policies or rules can be changed.

Action C: $\quad$ Your community's zoning ordinance has barriers to urban agricultural land uses, which may be resolved through simple ordinance amendments (see table 2 below for suggested amendments). Depending on your community, if more than three amendments are proposed, a longer process with a public input component may be required (see Action D). Discuss with your community's Planning or Community Development Department the best process to make needed amendments.

Action D: $\quad$ Your community's zoning ordinance and other ordinances do not have adequate, clear allowances for urban agriculture and gardening. First, find out if urban farmers and gardeners have encountered frustration with municipal permissions. If not, no changes to the ordinances may be necessary. If they have, discuss with the Planning or Community Development Department as well as the elected officials in your community the need to change current policies and laws. Working with city officials, a public education and input process should be undertaken to determine what uses are best where and under what circumstances. This process could be part of a communitywide master plan or update. The process should take at least a year, involve at least three different means of community input (e.g., meetings, surveys, interviews) and may require a consultant if city staff does not have time or expertise. 


\section{Appendix B. Suggested Amendments and Policy Changes To Allow Urban Agriculture}

\begin{tabular}{|c|c|c|}
\hline Question & Topic & Suggested Amendment \\
\hline 4 & Definitions & $\begin{array}{l}\text { Add definitions of all allowed agricultural or gardening uses, and make } \\
\text { sure they are compatible with any state laws, especially Right to Farm } \\
\text { legislation. }\end{array}$ \\
\hline 5 & Zoning Lot & $\begin{array}{l}\text { Add zoning lot definition and amend to allow zoning lot as a single lot } \\
\text { under zoning. }\end{array}$ \\
\hline 7 & $\begin{array}{l}\text { Secondary/Accessory } \\
\text { Agricultural Use }\end{array}$ & $\begin{array}{l}\text { Allow agriculture or gardening as a second use referencing case law, } \\
\text { (state and federal laws on educational and religious uses in } \\
\text { particular). A public input process like that in Action D may be } \\
\text { necessary. }\end{array}$ \\
\hline 8 & $\begin{array}{l}\text { Market Farms and } \\
\text { Right-to-Farm }\end{array}$ & $\begin{array}{l}\text { Hire counsel to review state right-to-farm legislation and determine if } \\
\text { current regulations on market farms comply. Change if need be. }\end{array}$ \\
\hline 13 & Temporary Fences & $\begin{array}{l}\text { Lengthen temporary fence time period to that of the growing season } \\
\text { for garden or agricultural areas. }\end{array}$ \\
\hline 14 & Fences & Allow affordable, appropriate fences for gardens. \\
\hline 15 & Parking Requirements & $\begin{array}{l}\text { Define number of spaces needed for use that would not disturb } \\
\text { neighbors. This could be done on a case-by-case basis. }\end{array}$ \\
\hline 16 & Loading Requirements & $\begin{array}{l}\text { Decide whether loading space(s) are needed. This could be done on a } \\
\text { case-by-case basis. }\end{array}$ \\
\hline 17 & Signs & $\begin{array}{l}\text { Allow for signs of the appropriate size and height that communicate } \\
\text { what the site is, fit in with the surrounding area, and are affordable. }\end{array}$ \\
\hline 18 & Screening & $\begin{array}{l}\text { Determine whether a fence or landscaping is needed to protect } \\
\text { privacy and health of neighbors. This could be done on a case-by-case } \\
\text { basis. }\end{array}$ \\
\hline 19 & Composting & Allow composting. A public education component may be necessary. \\
\hline 20 & Weeds & $\begin{array}{l}\text { Exclude food crops from the weeds definition in any weed or nuisance } \\
\text { ordinance. }\end{array}$ \\
\hline 21 & Garbage & $\begin{array}{l}\text { Define containers required and party responsible for pick-up of } \\
\text { garbage at urban agricultural or gardening sites in refuse ordinance. }\end{array}$ \\
\hline 22 & Water & $\begin{array}{l}\text { Allow urban agricultural or gardening uses to hook up to municipal } \\
\text { water. This may be a policy change rather than an ordinance } \\
\text { amendment. }\end{array}$ \\
\hline 23 & Prescribed Burn & $\begin{array}{l}\text { Amend fire or air pollution ordinance to allow a controlled burn with a } \\
\text { permit and certain conditions. }\end{array}$ \\
\hline 24 & Parks & $\begin{array}{l}\text { Allow for picking of crops from a community garden in a municipal } \\
\text { park. }\end{array}$ \\
\hline
\end{tabular}

